Article

\title{
Impact of Corporate Social Responsibility on Value Creation from a Stakeholder Perspective
}

\author{
Josefina Fernández-Guadaño * (iD) and Jesús H. Sarria-Pedroza \\ Accounting and Finance Department, Faculty of Economics, Complutense University, E-28223 Madrid, Spain; \\ jsarria@ucm.es \\ * Correspondence: jofernan@ucm.es
}

Received: 15 May 2018; Accepted: 7 June 2018; Published: 18 June 2018

check for updates

\begin{abstract}
In recent years, we have witnessed how companies and institutions have devoted significant effort to developing Corporate Social Responsibility (CSR) policies, basing their decision on the improvement in company results and the subsequent benefits for shareholders and other stakeholders. CSR means that managers must go beyond the mere satisfaction of the shareholders and take steps to establish balanced relations with all their stakeholders. The principles behind the CSR approach empower stakeholder governance. To test whether CSR policy constitutes a factor in value creation for shareholders and certain stakeholders such as employees, creditors and the State, we conducted an explanatory study, using a Correlated Random Effects approach, which compares the socially responsible companies included in the Spanish sustainability index, FTSE4Good Ibex, with the companies listed on the other indices of the IBEX family. On the one hand, the data show that sustainability reporting is well established in large companies in Spain but that it needs to be introduced more extensively in small and medium-sized enterprises. On the other hand, the findings point out that CSR has a positive and significant influence on the distribution of value in favor of the State, a negative influence for employees and no influence on other stakeholders.
\end{abstract}

Keywords: Corporate Social Responsibility (CRS); sustainability index; Spain; value creation; shareholder governance; stakeholder theory

\section{Introduction}

Modern society makes ever greater demands on companies that carry out actions aimed at achieving economically, socially, environmentally sustainable and responsible development. To adapt to the changes required by society, organizations must adopt strategic decisions in a number of spheres which makes it necessary to develop new models of efficient governance. These new models of corporate management must take into account the social and environmental implications of the company's activities as well as the interests of all the stakeholders [1]. In 2014, the European Commission put forward a new definition of Corporate Social Responsibility (CSR) as "the responsibility of enterprises for their impacts on society" [2] (p. 6).

There are a number of reasons for pursuing CSR activities, some of which are external to the company (e.g., global competition, legal obligations) while others are internal (e.g., management and/or employee initiatives). These reasons can be taken as drivers for change in business practice [3]. In Spain social corporate responsibility and environmental policies have been considered in recent years to be efficient policies for the good governance of companies. This has been the case for more than a decade, although the effects have been more permanent in large companies than in small and medium-sized ones.

In the European sphere, the Commission [4] has reiterated its commitment to a strong and prosperous single market which turns its focus once again to citizens and regains their confidence. 
In this context, corporate governance and CSR are key elements that also contribute to the competitiveness of European businesses, as well-managed and sustainable companies are better situated to contribute to the ambitious growth objectives established in the 2020 Strategy. In the same way, the Communication from the Commission to the European Parliament, the Council, the European Economic and Social Committee and the Committee of the Regions [5] recognizes that, in order to fully assume their social responsibility, companies must consider the interests of all the stakeholders in their business operations, and manage the impact that their activity has on them in order to maximize the creation of shared value for their owners/shareholders and for other stakeholders and society as a whole.

Likewise, the international business context has witnessed a retreat from an exclusive focus on shareholder wealth maximization. Many economists and academics have espoused the benefits of the stakeholder theory particularly in a global marketplace where long-term strategic planning is more valuable than short-term stock market price movements [6]. In this paper we wish to test whether benefits for the firms are shared among all stakeholders since in the study of corporate governance there has been a bias towards looking at shareholder interest in detriment to stakeholder interest. However, interest in the stakeholder government has increased in recent years. [7,8].

As institutional differences between different countries matter $[9,10]$, this paper aims to discover whether the development of CSR generates value for certain stakeholders such as shareholders, employees, State and creditors. by taking advantage of the fact that, since 2008, socially responsible companies in Spain have been listed in a separate FTSE4Good Ibex sustainability index. This study compares the socially responsible companies included in that index with those listed in the other indices of the IBEX family in order to analyze whether CSR practices can be a factor in value creation. If this can be demonstrated, it could be used to improve the development of CSR policies in different countries.

As a result, this paper has been organized as follows: in Section 2, a literature review examines the different approaches, theories and empirical studies, and the hypotheses of the study are posed. Section 3 presents the data, variables and the methodology and Section 4 provides the results of empirical analysis. Section 5 discusses the results and, finally, the Section 6 sets out the conclusions.

\section{Literature Review and Hypotheses}

Currently, there is a large number of different theories and approaches to Corporate Social Responsibility (CSR), which range from the Profit Maxim Approach to the Sustainability Approach. However, as Jamali and Carroll recognized recently [11], Stakeholder Theory is an important theoretical framework that is likely to make significant contributions to comparative studies of CSR in developed and developing countries.

CSR goes beyond the mere satisfaction of the shareholders or owners and takes steps to establish balanced relations with all the company's stakeholders. For this reason, we consider stakeholder theory to be a useful approach to guide companies towards the creation of value for all stakeholders $[12,13]$. Stakeholder Theory emphasizes that organizational stability and survival depends not only on satisfying the interest of the primary stakeholder, but must also enlist the support of all corporate stakeholders $[14,15]$. Stakeholder theory postulates, as a positive theory, "that CSR is pursued in order to understand and satisfy stakeholders. As a normative theory, it could be seen to prescribe stakeholder engagement, as a means to develop a successful business" [16] (p. 27).

CSR is one of the most reputational factors considered by employees [17]. Human resources policies, such as the participation of workers in decision-making, the possibility to participate in capital, labor flexibility, legal security and union relations all indicate a company's application of CSR with regard to its employees [14]. Furthermore, CSR policy is seen as a reputational indicator for the other stakeholders: Paying taxes in the country where the company does business and thereby contributing to the country's social development; paying interest and repaying loans in a timely manner, thereby generating a fluid relationship with the corresponding credit institutions; and guaranteeing the quality 
of the product/service provided to the end consumer. If we look at recent stakeholder literature, it can been seen that certain differences exist between stakeholder firms and non-stakeholder firms [12,18].

Indeed, CSR means complying with a series of principles which Wood [19] (p. 696) broke down into three areas: Legitimacy-firms must satisfy the demands and expectations of society and stakeholders; Public Responsibility—businesses are responsible for solving problems they have caused and issues related to their business operations and interest; and Managerial Discretion-managers have a responsibility to exercise good judgement and do 'what is right'.

These principles of CSR are what drive Stakeholder Governance, which is defined by Tirole [20] (p. 4) as "the design of institutions that induce or force management to internalize the welfare of stakeholders". For many years the shareholder government approach has prevailed. However, stakeholder governance has gained momentum in recent years [7]. This change is attributed to a growing interest in CSR because "an ethical posture combined with a loyal corporate brand community of customers can enhance corporate value" [3] (p. 2).

Different studies have been conducted regarding the effects of CSR on economic and financial performance, but the results are not conclusive [21]. Although we can find works in the literature that state that CSR does affect company results [22,23], the cause-effect relationship between the two is still not clear. Many results have indicated that a positive relationship exists but they are not entirely consistent [24]. In fact, previous evidence has resulted in contradictory conclusions [25], although a growing number of analyses indicate a positive link [26,27].

This paper seeks to contribute to the academic debate by following the methodology proposed by Poulain-Rehm and Lepers [7], which represents an innovative approach to operationalizing stakeholder value creation. In short, we wish to analyze whether CSR practices can represent a factor in value creation for shareholders, considered as a separate group of stakeholders, and for certain stakeholders, such as employees, the State and creditors, using as a sample the Spanish companies which make up the sustainability index. We issue then the following research hypothesis:

Hypothesis 1. CSR practices positively influence value creation for shareholders-considered as a separate group of stakeholders.

Hypothesis 2. CSR practices positively influence stakeholder value creation.

\section{Material and Methods}

\subsection{Data Collection}

The data have been collected both from the ORBIS database and from the Madrid Stock Exchange for the period 2012-2016. The companies in the sample were classified by distinguishing between the socially responsible companies on the Spanish Sustainability Index, the FTSE4Good IBEX, and those listed on the other indices of the IBEX family.

Moreover, last findings point out that the size variable is significantly associated with CSR [28-30]. Therefore, the sample has been classified into large companies (Ibex) and medium-sized companies (Ibex-Medium). The small firms (Ibex-Small) were excluded from the sample because only 1 in 20 had been included in the sustainability index during the period analyzed. In 2008, FTSE Group and the Madrid Stock Exchange (BME) jointly created the FTSE4Good Ibex index for the Spanish market. The inclusion criteria for the FTSE4Good are a set of constantly evolving CSR good practice standards. The FTSE4Good criteria are developed through an extensive consultation process with the market and are totally transparent. A wide range of interest groups contribute to define the admission criteria, among them NGOs, government agencies, consultants, academics, the investment community and the business sector [31].

Several groups were excluded from the sample: companies that did not have data in all the years in the period analyzed (2012-2016), companies that were excluded from the FTSE4Good Ibex during 
the period; banks and insurance companies because of their special financial characteristics and, finally, companies presenting negative value added (If we wish to observe how the value added is distributed among the different stakeholders, it does not make sense for this to be negative.) for one of the financial years included in the period.

The final sample included 40 companies: $65 \%$ large and $14 \%$ medium-sized. $72.5 \%$ are included in the sustainability index while $27.5 \%$ are not considered socially responsible. $35 \%$ of the companies belong to the secondary sector and $65 \%$ to the tertiary sector.

The distribution of the sample by size tells us that the majority $(88.46 \%)$ of the large companies are included in the sustainability index and $11.54 \%$ are not. For medium-sized companies the situation is the other way round, with $42.85 \%$ included in the sustainability index compared to $57.15 \%$ which are not. This therefore confirms the influence of size and capitalization which leads us to presuppose that the large companies in the sustainability index may exhibit more positive behavior both in terms of dividends to shareholders and towards their other stakeholders when compared with medium-sized companies. The data show that sustainability reporting in Spain is common practice for large companies but that it needs to be introduced more extensively in small and medium-sized enterprises.

\subsection{Variables}

\subsubsection{Dependent Variables}

Following Poulain-Rehm and Lepers [7], we adopted value added (Value Added is the difference between total sales revenue and total costs incurred obtaining that revenue, without including depreciation, interest, taxes and salary costs. It is also possible to calculate this as: Value Added $=$ Financial year result + Corporation Tax + Personnel Expenses + Depreciation Charges + Financial Expenses and similar.) distribution, in the accounting sense, as a dependent variable because the distribution of value added in favor of stakeholders, such as employees, creditors, the State and shareholders, can be measured using financial documents. The following ratios were calculated:

- For employees, the ratio of personnel costs to value added.

- For creditors, the ratio of interest and similar financial charges to value added.

- For the state, the ratio of profit tax to value added.

- For shareholders, the ratio of dividends to value added.

Financial statements and other reports contain comprehensive corporate information pertaining to interest groups such as creditors, employees, suppliers, customers and the community [32]. However, while shareholders' objectives are clear and quantifiable, other stakeholders lack an equivalent quantifiable objective [15] making it difficult to identify all the opportunity costs and prices [33]. This paper has used a series of proxies for stakeholder value (i.e., personnel costs, interest payment, profit tax and dividends), and yet we still have to deal with the lack of the specification of a trade-off for the various "value" dimensions implied in these proxies [34].

These measurements are limited and imperfect but as Poulain-Rehm and Lepers acknowledge [7] (p. 331) "they do not include the opportunity costs borne by the various stakeholders, but they represent an innovative approach to operationalize stakeholder value creation and were necessary to capture the effect they intend to present in the absence of any alternative measurements".

\subsubsection{Explanatory Variables}

Several categories of explanatory variables were included. The independent dichotomous variable is inclusion (or a lack thereof) in the FTSE4Good Ibex, which takes the following values: 0 for those companies not on the sustainability index and 1 for those that are included. A number of economic and control variables have been added because in last studies were significant. $t$ [7,35]: Financial risk and investment policy are included as is the variable Marg which represents Gross Operating Margin; 
with regard to size, large and medium-sized enterprises are differentiated. Furthermore, we included a dummy variable for the sector of economic activity (See Table 1).

Table 1. Summary of the variables included in the study.

\begin{tabular}{|c|c|}
\hline Abbreviation of Variable & Variables \\
\hline \multicolumn{2}{|c|}{ Shareholder and stakeholder value creation } \\
\hline EMPL & Personnel Cost/Value Added \\
\hline STATE & Profit Tax/ Value Added \\
\hline CRED & Interest Expenses/Value Added \\
\hline SHARE & Dividends/Value Added \\
\hline \multicolumn{2}{|c|}{ Explanatory and control variables } \\
\hline CSR & $\begin{array}{l}\text { Type of enterprise dichotomous variable: } \\
\text { CSR companies }=1 \\
\text { Non-CSR companies }=0\end{array}$ \\
\hline Size & $\begin{array}{l}0=\text { Large } \\
1=\text { Medium }\end{array}$ \\
\hline Sector & $\begin{array}{l}\text { Business activity } \\
\text { Secondary }=0 \\
\text { Tertiary }=1\end{array}$ \\
\hline Inv & Fixed Assets/Net Sales \\
\hline Debt & Debt Coefficient (Debt/Equity) \\
\hline Marg & EBITDA/Net Sales \\
\hline
\end{tabular}

Source: Author elaboration.

\subsection{Methodology}

In order to test the effects of CSR practices on shareholder and other stakeholders value creation, we develop an explanatory study and create four models to verify the current research hypotheses (VA): SHARE (Model 1), EMPL (Model 2), STATE (Model 3) and CRED (model 4). We estimated our models by using the Correlated Random Effects Approach (CRE): this is an alternative to Fixed Effects that still allows unobserved effects to be correlated with the observed explanatory variables [36,37]. Papke and Wooldridge [38] propose simple CRE methods when the response variable is a fraction or proportion.

The results of the Hausman test in the four models proposed rejects the null hypothesis thus indicating that we should use the Fixed Effects (FE) estimator. However, given that we have independent variables which are constant over time, we cannot use FE to estimate their effect. We therefore use CRE as a technique which adds to the model the average of the time-varying explanatory variables in a regression model with random effects (RE) in such a way that the coefficients associated with the variables would be a consistent estimate of the fixed effects, while the coefficients of the averages control the correlation between the error term and each of the explanatory variables. According to Wooldridge [36], as well as providing a synthesis of the FE and RE approaches, there are other reasons such as the fact that it provides a way to include time-constant explanatory variables in what is effectively a fixed effects analysis.

\section{Results}

\subsection{Descriptive Statistics and Correlations}

To accurately measure the characteristics of the sample, we performed a descriptive statistical analysis. As we can see, in Table 2, INV and MARG are higher for Non-RSC firms than for RSC firms while the DEBT coefficient is higher for RSC firms than for Non-RSC. EMPL, STATE and SHARE are higher on average for Non-RSC firms than for RSC while only CRED is higher on average for RSC than for Non-RSC enterprises. 
Table 2. Descriptive statistics for the sample.

\begin{tabular}{ccccccc}
\hline & \multicolumn{3}{c}{ Non-RSC Firm } & \multicolumn{3}{c}{ RSC Firm } \\
\hline & $N$ & Mean & Std. Dev & $\boldsymbol{N}$ & Mean & Std. Dev \\
\hline INV & 11 & 3.412 & 7.822 & 28 & 1.691 & 1.560 \\
DEBT (\%) & 11 & 96.04 & 86.91 & 28 & 176.16 & 109.25 \\
MARG (\%) & 11 & 30.72 & 23.79 & 28 & 22.83 & 20.76 \\
EMPL (\%) & 11 & 60.64 & 34.89 & 28 & 48.15 & 24.59 \\
STATE (\%) & 11 & 10.21 & 10.72 & 28 & 8.005 & 4.588 \\
CRED (\%) & 11 & 8.734 & 12.30 & 28 & 10.05 & 6.514 \\
SHARE (\%) & 11 & 14.47 & 15.55 & 28 & 13.35 & 14.19 \\
\hline
\end{tabular}

Source: Data compiled by the author.

Table 3 presents the correlations between the central variables in this study. There is a significant negative correlation between the variable EMPL with MARG, INV and STATE, CRED and SHARE. The variable STATE is positively correlated with SHARE and negatively correlated with DEBT. The variable CRED is significantly positively correlated with DEBT. Correlation coefficients between explanatory variables were tested to determine the absence of multi-collinearity problems.

Table 3. Correlations.

\begin{tabular}{|c|c|c|c|c|c|c|c|}
\hline & 1 & 2 & 3 & 4 & 5 & 6 & 7 \\
\hline $1 \mathrm{MARG}$ & 1 & & & & & & \\
\hline 2 INV & $0.658^{* *}$ & 1 & & & & & \\
\hline 3 DEBT & 0.056 & $0.371 *$ & 1 & & & & \\
\hline 4 EMPL & $-0.678^{* *}$ & $-0.627^{* *}$ & -0.128 & 1 & & & \\
\hline 5 STATE & $0.388^{* *}$ & 0.034 & $-0.414^{* *}$ & $-0.405^{*}$ & 1 & & \\
\hline 6 CRED & 0.188 & 0.665 & $0.547^{* *}$ & -0.397 * & -0.083 & 1 & \\
\hline 7 SHARE & 0.244 & -0.107 & -0.255 & -0.380 * & $0.546^{* *}$ & -0.147 & 1 \\
\hline
\end{tabular}

\subsection{Estimation Results of Regression Analysis}

In order to verify the two hypotheses we developed four models whose regression results are shown in Table 4. Model 1 is proposed as a means to test H1 and Models 2, 3 and 4 are proposed as a means to test $\mathrm{H} 2$. The findings show that $\mathrm{H} 1$ must be refuted, and $\mathrm{H} 2$ must be refuted except for State (Model 3). These results are not consistent with previous empirical findings [19].

All the models have a good fit as demonstrated by high Wald $\mathrm{Chi}^{2}$ values. The results of Model 1 (Table 4) show that that inclusion in the FTSE4Good Ibex does not exert a significant influence on Value Added, thus rejecting Hypothesis 1: CSR practices positively influence shareholder value creation. In this model only Inv, Debt and Marg are significant. The impact of investment variable results negative. Investment is then a value creation factor in the long term, but implies a decrease in dividends in the short term [7]. Debt appears to be negatively related to shareholder value creation. Marg is significant and positive in explaining the distribution of Value Added in favor of shareholders (SHARE). This result emphasizes the impact of the operating margin rate, as prescribed by the theory, and confirms that shareholders have priority when it comes to benefiting from the gross operating margin growth [7].

The results of Model 2 show, in Table 4, that CSR has a significant effect on EMPL, but the effect of CSR is contrary to what was expected because the relationship is negative and significant, thus obliging us to reject Hypothesis 2 as regards employees as one of the main groups of stakeholders. The. sector is also significant in favor of tertiary activities. 
Table 4. Correlation Random Effects Results.

\begin{tabular}{|c|c|c|c|c|}
\hline & Model 1: SHARE & Model 2: EMPL & Model 3: STATE & Model 4: CRED \\
\hline CSR & $\begin{array}{c}5.215761 \\
(3.919471)\end{array}$ & $\begin{array}{c}-16.97122 * * \\
(7.895296)\end{array}$ & $\begin{array}{l}2.686786^{* *} \\
(1.309001)\end{array}$ & $\begin{array}{c}3.190972 \\
(2.067954)\end{array}$ \\
\hline Size & $\begin{array}{c}2.683739 \\
(3.882001)\end{array}$ & $\begin{array}{c}6.111494 \\
(7.033997)\end{array}$ & $\begin{array}{c}0.8283411 \\
(1.298167)\end{array}$ & $\begin{array}{l}0.9945042 \\
(2.286708)\end{array}$ \\
\hline Sector & $\begin{array}{l}-5.611325 \\
(4.422362)\end{array}$ & $\begin{array}{l}11.42143 \text { * } \\
(6.508818)\end{array}$ & $\begin{array}{c}-0.031654 \\
(1141987)\end{array}$ & $\begin{array}{l}-1.421499 \\
(1.840179)\end{array}$ \\
\hline Inv & $\begin{array}{c}-0.7149134 \\
(0.04286637) *\end{array}$ & $\begin{array}{l}-2.112026 \\
(1.339275)\end{array}$ & $\begin{array}{l}1.026376^{* * *} \\
(0.1989623)\end{array}$ & $\begin{array}{l}1.43141^{* * *} \\
(0.1687892)\end{array}$ \\
\hline Debt & $\begin{array}{c}-0.0369556^{* *} \\
(0.0164485)\end{array}$ & $\begin{array}{c}0.0056113 \\
(0.0318415)\end{array}$ & $\begin{array}{c}-0.0239088^{* * *} \\
(0.0091391)\end{array}$ & $\begin{array}{l}0.0157627^{*} \\
(0.0093506)\end{array}$ \\
\hline Marg & $\begin{array}{c}0.04031802 * * * \\
(0.1242837)\end{array}$ & $\begin{array}{c}-0.4689958 \\
(0.3673092)\end{array}$ & $\begin{array}{l}0.0999509 * \\
(0.0561648)\end{array}$ & $\begin{array}{c}0.0086554 \\
(0.0494638)\end{array}$ \\
\hline Cons & $\begin{array}{c}18.23729 \\
(12.48487)\end{array}$ & $\begin{array}{l}41.05243 * * \\
(18.72438)\end{array}$ & $\begin{array}{l}5.9074444^{* *} \\
(2.810159)\end{array}$ & $\begin{array}{c}4.101317 \\
(4.603379)\end{array}$ \\
\hline Wald Chi ${ }^{2}$ & $15.60^{* * *}$ & $73.79^{* * *}$ & $79.82^{* * *}$ & $163.32^{* * *}$ \\
\hline rho & 0.21283591 & 0.69038156 & 0.05047149 & 0.29109907 \\
\hline N. obs & 195 & 195 & 195 & 195 \\
\hline N. firms & 39 & 39 & 39 & 39 \\
\hline
\end{tabular}

Significance levels: ${ }^{*} p<0.1,{ }^{* *} p<0.05,{ }^{* * *} p<0.01$. T Based on robust standard errors in parenthesis. Source: Data compiled by the author.

It can be seen that CSR (which differentiates between the firms included in the FTSE4Good Ibex and those which are not) in Model 3 does have a significant influence on STATE. The relationship is positive and partially confirms the second hypothesis as regards STATE as a secondary stakeholder. Indebtedness is negative and significant in explaining STATE value creation and Inv and Marg are significant and positive. It can be seen that only Shareholders and State have priority in benefiting from the activity and gross operating margin.

As we can see in Model 4, the difference in the type of company, CSR or Non-CSR, does not have a significant influence on CRED, and neither do any of the control variables except INV and Debt, which have a positive influence, thus obliging us to reject Hypothesis 2 as regards creditors as one of the secondary groups of stakeholders

\section{Discussion}

The results reveal that hyphothesis 1 is not proven and hypothesis 2is only proven for State. If the coefficients are observed, the CSR variable is significant in models 2 and 3 . The results show that CSR does not have an impact on shareholder value creation (H1) and, with regard to the influence of CSR on stakeholder value creation, a negative influence is observed in the EMPL variable and a positive influence in the STATE variable. These results do not coincide with some previous findings in relation to shareholders, employees and other stakeholders [14,21,39].

In the literature, human resource practices, such as working conditions and compensation policy, indicate a company's application of CSR towards employees [40]. According to Park et al. [14] (p. 969), by upgrading such corporate standards, companies "can satisfy employees, improve their job commitment, enhance financial and non-financial performance, and eventually secure internal momentum for CSR". However, our findings do not confirm this: In relation to the distribution of aggregate value towards employees, we did not detect improved economic performance in the companies included in the FTSE4Good Ibex. 
Recently, governments have come to be considered one of the drivers of change in corporate CSR policies because their regulation is decisive [41]. We have observed that many companies are seeking to locate to territories with a lower tax burden and this runs contrary to CSR. Our findings confirm that CSR appears to be positively related to State value creation.

According to our findingswe can summarize that hypothesis 1 has not been proven and that the hypothesis 2 has been partially proven. These results contradict the theoretical arguments concerning the effects of CSR policies on shareholder and other stakeholder value creation, but provide additional evidence of the lack of consensus regarding the effect of CSR on companies' economic performance.

\section{Conclusions}

Spain has been promoting CSR in its companies for more than a decade and although this has become common in large companies, it needs to be implemented more extensively in small and medium-sized enterprises. Institutions in Spain are promoting a range of policies in favor of good corporate governance and sustainability with the encouragement and support of the European Union, which considers CSR to be a key element of business competitiveness that will enable companies to be in optimum conditions for contributing to the ambitious growth objectives established in the 2020 Strategy.

We consider that stakeholder theory provides a useful framework for assessing the impact of CSR practices on business value added for shareholders and other stakeholders. To this end, we conducted an explanatory study aimed at analysing the differences between companies included in the FTSE4Good Ibex and those not included, using a CRE approach [36].

The results show that CSR does not have an impact on shareholder value creation (H1) and, as regards the influence of CSR on stakeholder value creation $(\mathrm{H} 2)$, a negative influence is observed on employees, as a primary stakeholder, and a positive influence is detected on States, as secondary stakeholder. Furthermore, the size variable, which differentiates large from medium-sized companies, is not a determining factor in our study.

However, this study does have limitations that should be addressed in future research. Firstly, our sample only includes large and medium-sized enterprises and the results could be different for micro and small companies. Future research should analyze this aspect and compare the results. Secondly, in order to prove/disprove the hypothesis, one must be able to measure "stakeholder value creation," which is one of the most difficult issues in Stakeholder Theory. It is known that while shareholders' objectives are clear and quantifiable (i.e., to maximize the net present/future value of the company's earnings), other stakeholders lack an equivalent quantifiable objective [15]. This paper has used a series of proxies for stakeholder value (i.e., personnel costs, interest payments, profit tax and dividends) but we recognize that these variables are limited [34]. This is, therefore, a quantitative study with the additional limitation of having only used accounting indicators. Future research should compile the qualitative indicators established in the Global Reporting Initiative by means of a survey and, in addition, should incorporate market ratios.

Our findings contribute to the literature on CSR by providing additional evidence regarding its effects on certain stakeholders. Although the results are not what would be expected, the current widespread use of sustainability indices makes it difficult for Spanish firms to ignore this issue and avoid making efforts to improve their stakeholder relations [21]. Moreover, an important number of the Europe 2020 initiatives make reference to CSR. Enhancing the strategic focus of CSR increasingly contributes to the development of a sustainable business model.

Author Contributions: J.F.-G. prepared the theoretical framework and the hypothesis, analyzed the data and wrote the results and conclusions. J.H.S.-P. reviewed the literature and prepared the theoretical framework and data collection.

Conflicts of Interest: The authors declare no conflict of interest. 


\section{References}

1. Gallardo, D.; Sánchez, I.; Castilla, F. Theoretical and Methodologial Framework for the Qualitative Validation of an Explanatory Model of Social Responsibility in cooperative societies. Revesco. Rev. Estud. Coop. 2015, 118, 86-121. [CrossRef]

2. European Commission. Communication from the Commission to the European Parliament, the Council, the Economic and Social Committee and the Committee of the Regions. A Renewed EU Strategy 2011-14 for Corporate Social Responsibility; $\operatorname{COM(2011)~} 681$ Final; European Commission: Brussels, Belgium, 2011.

3. Fukukawa, K.; Balmer, J.M.; Gray, E.R. Mapping the interface between corporate identity, ethics and corporate social responsibility. J. Bus. Ethics 2007, 76, 1-5. [CrossRef]

4. European Commission. Communication from the Commission to the European Parliament, the Council, the Economic and Social Committee and the Committee of the Regions. 27-10-2010. Single Market Act Twelve Levers to Boost Growth and Strengthen Confidence "Working Together to Create New Growth"; [COM(2010) 608 end]; European Commission: Brussels, Belgium, 2010.

5. European Commission. Communication from the Commission to the European Parliament, the Council and the European Economic and Social Committee-Implementing the Partnership for Growth and Jobs: Making Europe a Pole of Excellence on Corporate Social Responsibility; COM(2011) 681 End; European Commission: Brussels, Belgium, 2011.

6. Marshall, S.; Ramsay, I. Stakeholders and Directors' Duties: Law, Theory and Evidence. UNSWLJ 2012, 35, 291. [CrossRef]

7. Poulain-Rehm, T.; Lepers, X. Does Employee Ownership Benefit Value Creation? The Case of France (2001-2005). J. Bus. Ethics 2013, 112, 325-340. [CrossRef]

8. Bendixen, M.; Russel, A. Corporate identity, ethics and reputation in supplier-buyer relationships. J. Bus. Ethics 2007, 76, 69-82. [CrossRef]

9. Husted, B.W.; Filho, J. The impact of sustainability governance, country stakeholder orientation, and country risk on environmental, social, and governance performance. J. Clean. Prod. 2017, 155, 93-102. [CrossRef]

10. Mahmood, Z.; Kouser, R.; Ali, W.; Ahmad, Z.; Salman, T. Does Corporate Governance Affect Sustainability Disclosure? A Mixed Methods Study. Sustainability 2018, 10, 207. [CrossRef]

11. Jamili, D.; Carroll, A.B. Capturing advances in CSR: Developed versus developing country perspectives. Bus. Ethics Eur. Rev. 2017, 2, 321-325. [CrossRef]

12. Fassin, Y.; Colle, S.; Edwart Freeman, R. Intra-stakeholder alliances in plant-closing decisions: A stakeholder theory approach. Bus. Ethics Eur. Rev. 2016, 26, 97-111. [CrossRef]

13. Freeman, R.E. Strategic Management: A Stakeholder Approach; Pitman-Ballinger: Boston, MA, USA, 1984.

14. Park, B.I.; Chidlow, A.; Choi, J. Corporate social responsibility: Stakeholders influence on MNEs' activities. Int. Bus. Rev. 2014, 23, 966-980. [CrossRef]

15. Hansmann, H.B. Investor-Owned Firms. In The Ownership of Enterprise; The Belknap Press of Harvard University Press: Cambridge, MA, USA; London, UK, 2009; pp. 53-65.

16. Ditlev-Simonsen, C.D.; Midttun, A. What motivates managers to pursue corporate responsibility? A survey among key stakeholders. Corp. Soc. Responsib. Environ. Manag. 2011, 18, 25-38. [CrossRef]

17. Lindgreen, A.; Swan, V.; Johnson, W.J. Corporate Social Responsability: An empirical investigation of U.S. organizations. J. Bus. Ethics 2009, 85, 303-323. [CrossRef]

18. Ali, M.A. Stakeholder salience for stakeholder firms: An attempt to reframe an important heuristic device. J. Bus. Ethics 2017, 144, 153-168. [CrossRef]

19. Wood, D.J. Corporate social performance Revisited. Acad. Manag. Rev. 1991, 16, 691-718. [CrossRef]

20. Tirole, J. Corporate governance. Econometrica 2001, 69. [CrossRef]

21. Fernández-Guadaño, J. Measuring the economic performance of socially responsible companies. Proc. Rij. Fac. Econom. J. Econom. Bus. 2015, 33, 207-234. [CrossRef]

22. Orlitzky, M.; Schmidt, F.L.; Rynes, S.L. Corporate social and financial performance. Organ. Stud. 2003, 24, 403-433. [CrossRef]

23. Allouche, J.; Laroche, P. A meta-analytical investigation of the relationship between corporate social and financial performance. Rev. Gest. Ressour. Hum. 2005, 57, 18-31.

24. Moore, J. Corporate Social and Financial Performance: An Investigation in the U.K. Supermarket Industry. J. Bus. Ethics 2001, 34, 299-315. [CrossRef] 
25. Gómez García, F. Responsabilidad social corporativa y performance financiera: Treinta y cinco años de investigación empírica en busca de un consenso. Principios 2008, 11, 5-22.

26. Simpson, W.G.; Kohers, T. The Link between Corporate Social and Financial Performance: Evidence from the Banking Industry. J. Bus. Ethics 2002, 35, 97-109. [CrossRef]

27. Orlitzky, M. Social Responsability and Financial Performance: Trade Off or Virtuous Circle? Univ. Auckl. Bus. Rev. 2005, 7, 37-43.

28. Trotman, A.; Bradley, G. Associations between Social Responsibility Disclosure and Characteristics of Companies. Account. Organ. Soc. 1981, 6, 335-362. [CrossRef]

29. Arlow, P.; Gannon, M. Social Responsiveness, Corporate Structure, and Economic Performance. Acad. Manag. Rev. 1982, 7, 235-241. [CrossRef]

30. Prado, J.M.; Gallego, I.; García, I.M.; Rodríguez, L. Social Responsabilty in Spain, Practices, and Motivations in Firms. Manag. Decis. 2008, 46, 1247-1271. [CrossRef]

31. FTSE. FTSE4Good IBEX Index. Research and Analysis Report. 2008. Available online: http://www.ftse.com/ Indices/FTSE4Good_IBEX_Index/Downloads/FTSE4Good_IBEX_Research_Report_Spanish.pdf (accessed on 15 June 2016).

32. Yang, S.; Ye, H.; Zhu, Q. Do Peer Firms Affect Firm Corporate Social Responsibility? Sustainability 2017, 9, 1967. [CrossRef]

33. Charreaux, G.; Desbrières, P. Gouvernance des entreprises: Valeur partenariale contre valeur actionnariale. Financ. Contrôle Strateg. 1998, 1, 57-88.

34. Jensen, M.C. Value Maximization and the Corporate Objective Function. In Breaking the Code of Change; Beer, M., Nohria, N., Eds.; Harvard Business School Press: Boston, MA, USA, 2000; pp. 37-57.

35. Fernández-Guadaño, J.; López-Millán, M. Employee-Owned Firm from a Stakeholder Perspective. J. Int. Dev. 2018. [CrossRef]

36. Wooldridge, J.M. Introductory Econometrics: A Modern Approach; Nelson Education: Scarborough, ON, Canada, 2015.

37. Chamberlain, G. Multivariate regression models for panel data. J. Econom. 1982, 18, 5-46. [CrossRef]

38. Papke, L.E.; Wooldridge, J.M. Panel Data Methods for Fractional Response Variables with an Application to Test Pass Rates. J. Econom. 2008, 145, 121-133. [CrossRef]

39. Hartman, L.P.; Rubin, R.S.; Dhanda, K.K. The communication of corporate social responsibility: United States and European Union multinational corporations. J. Bus. Ethics 2007, 74, 373-389. [CrossRef]

40. Mishra, S.; Suar, D. Does corporate social responsibility influence firm performance of Indian companies? J. Bus. Ethics 2010, 95, 571-601. [CrossRef]

41. Qu, R. Effects of government regulations, market orientation and ownership structure on corporate social responsibility in China: An empirical study. Int. J. Manag. 2007, 24, 582. 